\title{
Urban sprawl and residential segregation in Western Suburb Area of Malang City, East Java, Indonesia
}

\author{
Satti Wagistina*, Antariksa** \\ * Department of Geography, Faculty of Social Sciences, Malang State University \\ ** Department of Architecture, Faculty of Engineering, Brawijaya University
}

\begin{tabular}{l}
\hline \hline INFO ARTIKEL \\
\hline Riwayat Artikel: \\
Dikirim: $22-4-2018$ \\
Disetujui: $31-5-2018$ \\
Diterbitkan: $31-1-2019$ \\
Keywords: \\
urban sprawl; residential \\
segregation; social segrega- \\
tion; spatial expression; \\
migrants-natives
\end{tabular}

\begin{abstract}
ABSTRAK
Abstract: Aim of this study is to analyze the impact of urban sprawl on the residential and social segregation in western suburb area of Malang city. This research has been conducted through combination of qualitative and quantitative methods or mixed method. Quantitative method was undertook to identify the urban sprawl. Urban sprawl was detected by means of urban morphology approach. Quantitative method was represented by: (1) the processing of Normalized Difference Built up Index to identify the built-up area growth and (2) delineation of residential area types taken from Google earth and ground checking at the study location. Qualitative method was done by using the hermeneutical phenomenology to investigate the social segregation. Research's result showed that there is urban sprawl, impacting on spatial structure changes. Spatial structure has been shown by the alteration of non-built-up areas into planned settlements separated from village, further referred as residential segregation. Residential segregation shows that there is social segregation between the migrants and natives in western suburb area of Malang city. This research concludes that the urban sprawl has implication on shifting process of rural to suburb area. However, the shifting process does not impact on systematic social dimension between the migrants and natives.
\end{abstract}

Abstrak: Tujuan dari penelitian ini adalah untuk
menganalisis dampak perambahan perkotaan terhadap
segregasi permukiman dan sosial di daerah pinggiran barat
kota Malang. Penelitian ini dilakukan melalui kombinasi
metode kualitatif dan kuantitatif atau metode campuran.
Metode kuantitatif dilakukan untuk mengidentifikasi
perambahan kota yang terdeteksi melalui pendekatan
morfologi perkotaan. Metode kuantitatif diwakili oleh: (1)
pengolahan "Normalised Difference Built Up Index" untuk
mengidentifikasi pertumbuhan area terbangun dan (2)
penggambaran tipe-tipe area pemukiman yang diambil
melalui Google Earth ${ }^{\text {TM }}$ dan cek lapangan di lokasi penelitian.
Metode kualitatif dilakukan dengan menggunakan
fenomenologi hermeneutis untuk menyelidiki segregasi
sosial. Hasil penelitian menunjukkan bahwa ada perambahan
perkotaan (urban sprawl) berdampak pada perubahan struktur
spasial. Struktur tata ruang telah ditunjukkan oleh perubahan
daerah-daerah yang tidak dibangun menjadi pemukiman-


pemukiman terencana yang terpisah dari desa, yang selanjutnya disebut sebagai segregasi perumahan. Pemisahan pemukiman menunjukkan bahwa ada segregasi sosial antara pendatang dan penduduk asli di daerah pinggiran barat kota Malang. Penelitian ini menyimpulkan bahwa urban sprawl memiliki implikasi pada pergeseran proses dari pedesaan ke daerah pinggiran kota, akan tetapi proses pergeseran tidak berdampak pada dimensi sosial yang sistematis antara pendatang dengan penduduk asli.

\author{
Address Correspondence: \\ Satti Wagistina \\ Department of Geography \\ Faculty of Social Sciences \\ Malang State University \\ E-mail: satti.wagistina.fis@um.ac.id
}

\title{
INTRODUCTION
}

Existence of sprawl has affected on the increasingly widespread city development. Suburb areas are city development activities overtopping with all their consequences. Facility provision (infrastructure) is difficult due to inefficiency which was reflected through agricultural land speculation, making it difficult for city spatial planning affecting on considerable infrastructure procurement cost. Sprawl phenomenon also changes the rural spatial structure into urban areas; therefore, the rural area functioning as the buffer zones turns into suburbs. Even the urban sprawl also causes the urban bias.

Malang is a great city leading into a metropolitan city as its population is nearing 1 million people. Malang competitiveness out of 24 major cities in Indonesia is quite good and serves as the centre of activity (Santoso, 2009). Malang as a big city has urban area specialization. It is rare that the big cities lead to the metropolis as well as the more specialized ones clearly as Malang. The specialization as the educational city makes Malang dominated by students with an average of 30,750 people/ annum. The data from the Department of Population and Civil Registration (2017) showed that $48 \%$ of population growth is due to Malang migration; $36 \%$ is due to births; and $15 \%$ is due to deaths. This shows that the population mobilization into Malang tends to increase by the motivation not only for education (75\%) but also for employment (25\%). This means that Malang growth is mostly caused by urbanization.

Urbanization process is unstoppable in Malang, and thus the space demand for newcomers cannot be fulfilled. This is apparent from the residential densification towards the suburb of Malang City. The residential densification slowly creates the urban sprawl in the suburb of Malang City. The urban sprawl appears on many things; one of which is from new residential areas developed by private sectors, having scattered and unfocused patterns and not forming space agglomeration.

Suburb areas in this research are areas imaginarily shown in Malang map, which are attached to Malang city and seen as if they were urban fringe areas. The northern suburb area undergoes faster sprawl development than other suburbs. Western suburb area (WSA) has undergone the sprawl acceleration since the campus complex development in 1991. The southern suburb area undergoes relatively fast sprawl due to its location factor which is close to the Central Business District (CBD) core and frame of Malang. Eastern suburb area undergoes relatively slow sprawl compared to other suburbs. This is because the eastern suburb locations do not relate to other areas. In other words, sprawl 
development is determined by the suburb area physical character. Therefore, the sprawl process in suburb areas with high accessibility to the prime city will be balanced with the urbanization process and settlement densification, thus becoming a suburb area towing power (Wagistina et al, 2017).

Urban sprawl followed by settlement densification implies that the number of migrants is increasing along the suburb areas. Accordingly, there has been intensified interaction between migrants and natives. Most migrants reside in planned and independent settlements; however, local residences or natives reside in their kampong (native settlement) areas.

Urban sprawl and unplanned one in the urban planning are almost in all cities worldwide, especially in developing countries. Cities develop in limitless scales and cause some social, economic, and physical environmental problems. Negative effect of urban sprawl to the environment and resources among others are the agricultural land conversion into residential areas, air pollution, traffic jam, losing of cultural heritage, as well as social and racial segregation (Vaz et al, 2014; Bruckner et al, 2008; Glaeser et al, 2003; Broitman et al, 2015). Even, in United States, the urban sprawl has caused widespread negative effects, namely the resource depletion and social problems. Resource depletion is shown by the lowering of ground water and aquiver, the increasing variation of medium-sized city temperature of $25 \%$ and topography change as the results of residential construction (Overman, 2006).

New and planned settlements are inhabited by migrants with relatively different social, cultural, and economic background from the natives. Almost all migrants work in the formal sector with a minimum education level of High school. Unlike the case in the natives, they relatively have diverse jobs and educational levels.

Location of new and planned settlements does not integrate to the original settlement and forms the spatial expression which is not fused. Spatial expression is not only physically, but also socially. The results show that the spatial physical changes are caused by new settlement development and inhabited by migrants, having effects on social change in local communities or natives (Maru et al, 2016; Sun, 2011; Kinanti et al, 2013). However, this current research differs considerably from the previous studies. The significant difference lies on its focus on analyzing the effect of urban sprawl to spatial and social segregations in WSA of Malang city.

Based on these descriptions, the problem formulation in this research is how does the urban sprawl have effects on the spatial and social segregations in WSA of Malang city? This study aims to analyze the impact of urban sprawl on the residential and social segregations in WSA of Malang. Spatial segregation is made apparent by the segregations of planned and original settlements, as well as by spatial patterns formed by unplanned use of lands.

This research presents the description of urban planning and design information which are not integrated among all areas in Malang, as well as its effects. Therefore, it is expected that this research's results can be used as the consideration in the preparation of integrated and sustainable urban development planning.

\section{METHODS}

This research is ex post facto by means of positivistic and interpretive approaches. Analytical method used in this research is the combination between phenomenology and descriptive. The descriptive method is used to analyze changes in land use with data from spatio temporal analysis and the Central Statistics Agency (BPS) of Malang. To detect the sprawl, the Landsat satellite image data of Malang in 1995 and 2015 were used. 
Identification of urban sprawl in this current research made use of urban morphology approach. Sprawl indicator is the change of land use from non-built-up area into built up area. Data are derived from the Landsat 4 in 1995 and Landsat 8 (LDCM 8) in 2015. Imagery data are further transformed into built-up land data by means of Normalized Difference Built up Index (NDB) formula as follow:

$$
\begin{aligned}
& \text { NDBI }=\frac{\boldsymbol{N I R}-\boldsymbol{S W I R}}{\boldsymbol{N I R}+\boldsymbol{S W I R}} \\
& \text { NDBI }=\text { Value by Normalized Difference Built-up Index } \\
& \text { NIR }=\text { Value of reflection from near infrared } \\
& \text { SWIR }=\text { Value of reflection from SWIR (Short Wave Infrared) }
\end{aligned}
$$

Wagistina et al (2017) have revealed that the growth of built-up areas in western suburb areas from $1995,2000,2003,2010$, to 2015 has shown to be $58.28 \%$. It can be implied that unplanned non-built-up areas have undergone transformation particularly in western suburb area of Malang city.

To identify the residential segregation, the data from Google Earth ${ }^{\mathrm{TM}}$ as the software mapping are used and able to present the residential images with the resolution of $15 \mathrm{~m}$ per pixel. Google Earth ${ }^{\mathrm{TM}}$ delineation is conducted to set the line limit between new residential and native settlements. Ground check of study location is used to know the limit between the new residential and native settlements; then the limits are presented in this figure.

Phenomenology method is used to analyze the social segregation between migrants and natives. Main attention is the social segregation problem and experience structure of the phenomenon in the lives of migrants and natives. Data are obtained by the in-depth interview with the informants, then analyzed and checked by the triangulation logics (Suman, 2012; Fatchan, 2013). Triangulation in this current research is that phenomenology method results are rechecked by means of quantitative descriptive method to strengthen validity between data finding of participant observation results and secondary data obtained from Central Bureau of Statistics of Malang District.

Study location is set by purposive sampling with consideration of relatively close distance to Malang City as the prime city; location is in the primary arterial roads; relatively fast sprawl development compared to the sprawl in eastern and northern suburbs area; as well as the high affordability level into the prime city compared to other suburbs. By these considerations, the western part of Malang city is chosen as the study location. The data used are the secondary and primary data from the key informants. Documentation is also conducted to prove the data from the real image at the study location (ground check).

\section{RESULT DAN DISCUSSION}

In 1995, built up area in suburb areas of Malang city was 627.07 ha, increasing to 1367.11 ha in 2016. It has been an increasing number of 740.04 ha built up areas within 20 years. In two decades, the built up lands in western suburb areas have shown to be the highest, accounting for $84.99 \%$ out of all suburban areas in 2016. Most of built up areas are new residential areas developed by the developers. New residential areas are paddy field conversion; it causes the paddy field to decrease. 
Urban sprawl process is the city development into the suburb area (urban fringe), started by the residential development. Further effect is the migration from city to the suburb (suburbanization), and transformation of economic activities from the agriculture into non-agriculture (Giyarsih, 2001; Nechyba et al, 2004; Wagistina, 2017). Urban sprawl process is the sprawl and unplanned one in the urban planning.

If compared to other suburb areas, WSA has been categorized as the fastest growing residential area. This is supported by the location, place, and affordability factors. WSA is in primary corridor relating the prime city (Malang City) and the southern and western areas of East Java Province. This condition is supported by the relatively fast development of Batu City as the icon of tourism spot in East Java. The distance between Batu City and WSA is only $7 \mathrm{kms}$; also the distance to the Malang city is less than $8 \mathrm{kms}$, affecting on high interest of newcomers to stay. It implies that the affordability of WSA is higher than other suburb areas in Malang.

New residential distribution and other non-built up area in WSA is the spatial phenomenon called as sprawl. Sprawl characteristics are indicated by the use of unnecessary land in solving the open space; there is a wide gap between physical development and widespread land use, the separation of the spatial use, and the gap between the public space and the community centre (Mohammadi et al, 2012; Habibi et al, 2011; Pontoh et al, 2009; Overman, 2006; Giyarsih, 2001).

Sprawl in WSA has the characteristic of agricultural lands used for residential areas, the shop-house construction utilizing agricultural lands and native residential, and the planned (new) residential areas separated from the native settlements. It occurs in relatively close areas to the primary arterial road, which is the road connecting Malang Municipality-Malang Regency-Batu Municipality.

New residential development is uncontrolled, separated from the native and unplanned ones. As if there were no local government control, the developers tended to ignore the possibility of negative consequence from the new residential development. The residential developers ignore the spatial environment proven by: a) the agricultural land conversion, b) sprawl and unplanned residential development, and c) un-unified residential location with the native settlements or kampong.

Table 1. Development Ratio of Residential Area to the Area in WSA Malang City

\begin{tabular}{clcc}
\hline No & \multicolumn{1}{c}{ Descriptions } & $\begin{array}{c}\text { Housing\& } \\
\text { Kampong }\end{array}$ & \% to Area \\
\hline 1 & 1995 & $109,182 \mathrm{Ha}$ & 9.40 \\
\hline 2 & 2016 & $193,993 \mathrm{Ha}$ & 16.70 \\
\hline 3 & WSA Area & \multicolumn{2}{c}{$1161.88 \mathrm{Ha}$} \\
\hline 4 & $\begin{array}{l}\text { The proportion of residential area on the } \\
\text { built up area }\end{array}$ & \multicolumn{2}{c}{$16.69 \%$} \\
\hline 4 & Residential Area Growth & \multicolumn{2}{c}{$77.68 \%$} \\
\hline 5 & $\begin{array}{l}\text { Rate of Residential Area Growth } \\
\text { Source: }\end{array}$ & \multicolumn{2}{c}{$3.88 \% /$ year } \\
\end{tabular}

The results have revealed that the proportion of residential areas towards suburb areas increased $7.30 \%$ from 1995 to 2017 . Residential areas' growth considerably increased in averagely $3.88 \%$ per year. The growth of built up lands has been dominated by residential areas separated from native settlements. Growth of residential areas and presence of migrants residing in those areas are the eminent impacts of urban sprawl. Below is the map displaying the use of lands in WSA of Malang City. 
Jurnal Pendidikan Geografi:

Kajian, Teori, dan Praktik dalam Bidang Pendidikan dan Ilmu Geografi

Tahun 24, Nomor 1, Jan 2019, Hal 11-24

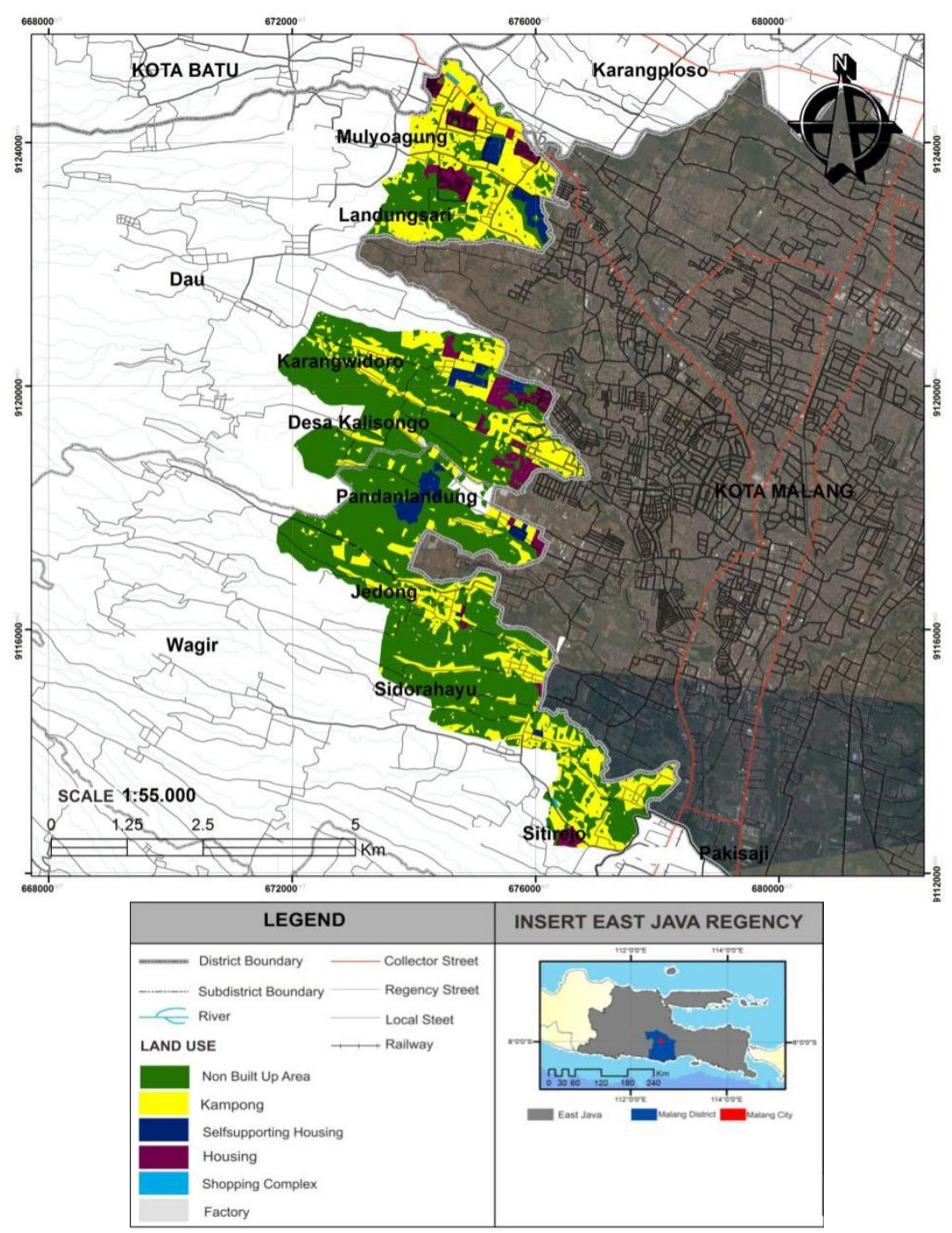

Figure 1. The Land Use Map in WSA

Larger residential areas indirectly imply that the number of migrants in WSA has been increasing. Process of those migrants moving to WSA is known as suburbanization. Suburbanization simultaneously results in land consumption by migrants extant through the emergences of housing following imperfect market competition.

Basically, the sprawl phenomenon in WSA is caused by two forces namely centrifugal and centripetal forces (Daljoeni, 2003; Fellmann et al, 2007; Colby, 2009). Centrifugal force is greater than the centripetal force, which characterized by horizontal pattern, with urban area decisive expansion and built-up areas. Driving factor of centrifugal force is spatially derived from the prime city of Malang. Malang population density in 2015 was 7,938 inhabitants/ km sq and was high when compared to any other cities such as Bogor and Medan. Residential space need is also high and thus the supply and demand are not linear. It has resulted in the very high price of land and houses in Malang city. Migrants in Malang further seek for relatively close residential location to prime city, affordable prices, high accessibility, and a comfortable environment. Upon these considerations, WSA is a destination location and there gradually forms residential agglomeration developed by housing developers. Research which was conducted by Serlin 
et al (2013) and Sastrawati et al (2011) revealed that accessibility, water, electricity, economic facilities, and housing prices are the primary considerations for the urbanites in choosing the residential location.

The process serves as a push factor for the sprawl acceleration in WSA. This thrusts the land use conversion and new spatial function development such as the residential, trade, tourism, office, service, and commercial functions. Residential function has dominant role in the creation of the urban process even it is the main trigger in changing process of spatial expression in western suburbs.

In addition to the centrifugal force, there is also a centripetal force from internal strength of WSA in Malang city. The internal strength in WSA is the environmental and locational rent (Rustiadi et al, 2011). Both are the overlaps between the economic and the environment interests. WSA is relatively close to Malang City, UMM campus location, and located in the primary arterial road connecting Malang City to the central and western areas of East Java Province. The relatively cheap land price is the trigger for the developers to compete to build residential areas. In addition to the housing developers, there are also migrants who independently build their residential areas. The reality is that the housing developers tend to ignore the ecological (environment) functions and always give priority to the economic (rent) factors from the paddy land-use conversion into residential areas.

Centripetal and centrifugal forces causing the urban sprawl's result in spatial expression of the WSA changes. The changes are from rural into suburb areas. Agricultural lands are also changed into residential and supporting physical infrastructure like shopping centres in suburb area along the roads of Landungsari-Jetis-Sengkaling. This land use pattern is called as informal land conversion process and is followed by the OBSP formula namely occupation, building, servicing, and planning (Nurmandi, 2014). Occupation starts from suburbanite presence occupying 12 planned and self-sufficient residential areas. The increasing total population has affected on the residential supporting physical infrastructure development (building and servicing) such as the establishment of Integrated Waste Disposal (TPST) Mulyoagung Unit, clean water management by non-governmental, shopping and recreation park of Sengkaling by private and public sectors, basic education schools by private sectors, and road construction environment independently.

Sprawl gradually causes the conurbation, namely rural development into unplanned urban (Daldjoeni, 2003; Soetomo, 2002; Fellmann et al, 2007; Yunus, 2010). Physical spatial changes in WSA occur sporadically and without planning. Open space conversion is fully into residential, shops, cafes, and business places. Developers always get the building permit (Ijin Mendirikan Bangunan/ IMB) from Malang government. Conurbation is shown from the uncontrolled residential densification, socio-economic activities shift from the informal into the formal, and the growth of Malang as the prime city which is growing rapidly but not integrated with border areas. From the conurbation characteristics, the densification settlements show a very rapid development in comparison to the other characteristics (Ambarwati et al, 2014).

Informal land conversion process is formed by the sprawl spatial expression with elongated pattern or ribbon development. Ribbon development indicates land use conversion from agriculture to residential areas located along the transport route connecting Malang Municipality and Batu Municipality as well as other regions (Yunus, 2012). Private and public sectors are only interested in building the physical suburb area following the transport path (line) so that it is uneven. As a result, the economic and social activities' concentration of WSA is only around the primary arterial roads of Malang Batu. 
Jurnal Pendidikan Geografi:

Kajian, Teori, dan Praktik dalam Bidang Pendidikan dan Ilmu Geografi

Tahun 24, Nomor 1, Jan 2019, Hal 11-24

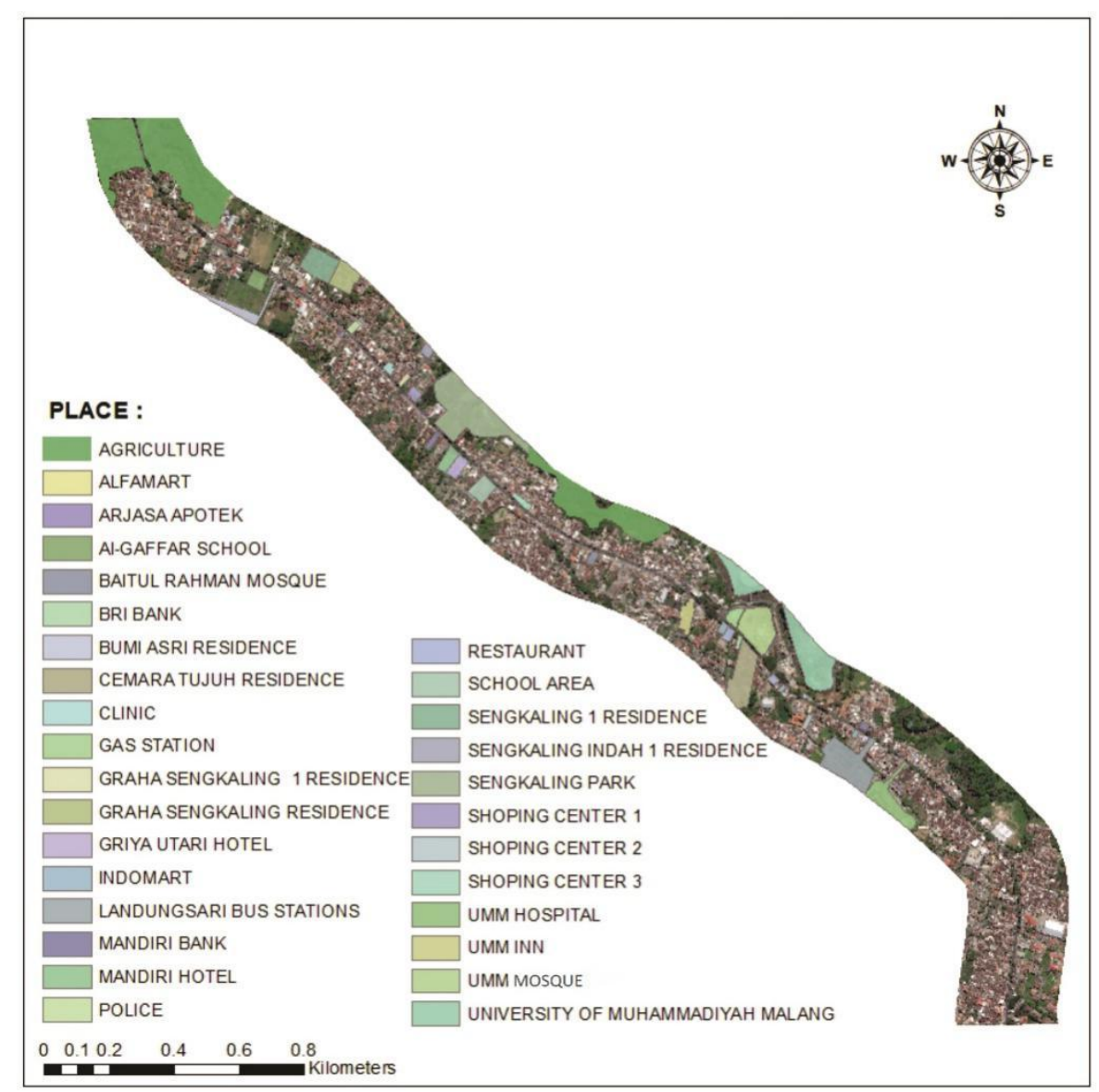

Figure 2. Sprawl Spatial Pattern in WSA of Malang City with Ribbon Shape

The sprawl in WSA is started by planned residential construction utilizing agricultural lands, so that gradually there is residential densification. Simultaneously, there are also residential densification and housing market mechanism. There are housing demands by migrants and the housing supply by developers by following the imperfectly competitive market as the residential market theory by Blair (1991) stating that there is housing market mechanism by the uncertainty element, so that the supply side and the demand follow the imperfect competitive market. Marketing of housing in Indonesia is performed by private sectors and most of which are offered to upper-middle class society (Dolling et al, 2014). This sort of housing is non-subsidized by the government. Most of subsidized housings are low-cost housing types, as those existing in suburb areas in America and Europe (Rubenstein, 2008).

Phenomenon since 2010 that there was home ownership trend which in general was uninhabited and functioned as a vacation place by migrants. Almost every residential area has the houses which are only used at certain times. The owner usually comes from outside Malang. At the end, the sprawl is becoming increasingly unmanageable, because the housing ownership is not only based merely on the demand.

Spatial expression in WSA as a result of centrifugal and centripetal force is very clear. The expression is shown by the residential spatial difference between the unplanned, independent, and native residential areas 'kampong', which in turn creates the phenomenon of residential segregation. There is no firm edge between the three types of residential areas; however, indirectly, the edge is formed because of the physical and non-physical spatial segregation process, forming the residential space. 
Formerly, discussion about residential segregation phenomenon was initiated in America, experienced by Blacks and the other minorities (Blair, 1991). Segregation constitutes a combination between congregation and discrimination group that occurs spatially. Geographers identify three principles of segregation in spatial dimension; they are: enclaves, ghettos, and colonies (Knox et al, 2016). Residential segregation in WSA is described by the following figure.

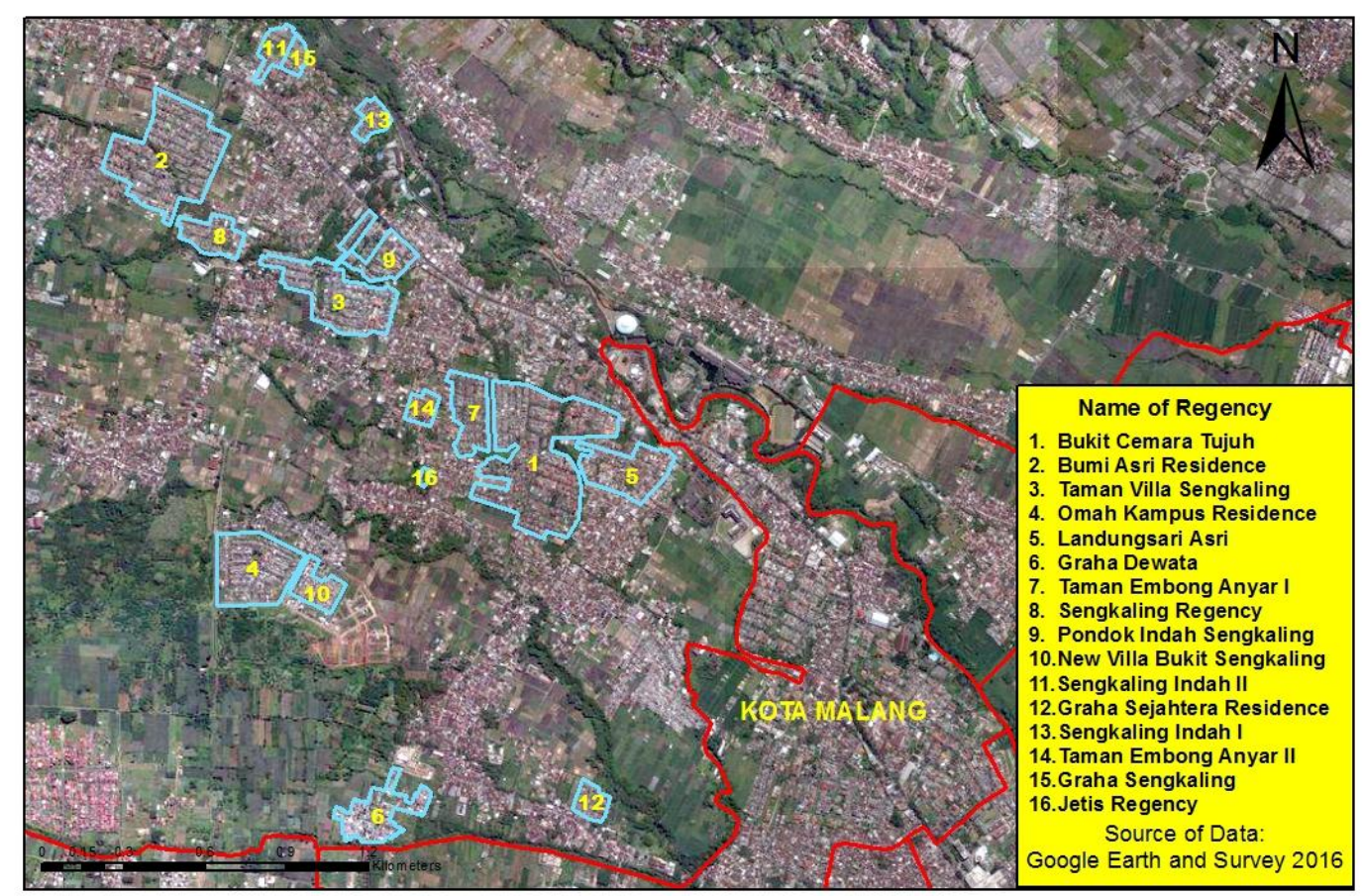

Figure 3. Residential Segregation in WSA of Malang City

16 planned residential areas in WSA show relatively homogeneous spatial expression. Homogeneity is shown from the residential area occupying productive agricultural land; clean water source is groundwater; type of modern architecture is ranging from simple, luxurious, to very luxurious; and having no integrated road environment with rural located along the roads of Jetis, Mulyoagung and Sengkaling within a radius of 100 meters to 200 meters. Pondok Indah Sengkaling, and Sengkaling Indah I and II estates have only 100-meter distance from arterial road. The longest distance is 200 meters namely Taman Embong Anyar I, II, and Sengkaling Regency.

Residential segregation as a form of spatial segregation shows the diversity and disparity of people's socio-economic conditions also with the mechanism change (Blair, 1991; Mubarak, 2004; Fellmann et.al, 2007; Greenstein et al, 2010; Liu et al, 2015). The planned, independent, and kampong residential spatial expression directly describes socioeconomic conditions of settlers. Out of 12 planned residential locations, Bukit Cemara Tujuh estate belongs to the type of luxurious to very luxurious residential location. This building area is $110 \mathrm{~m}^{2}$ to $350 \mathrm{~m}^{2}$ with price ranges from 715 million IDR to 1.7 billion IDR. Mr.Y (32 years old) as security guard at this estate, said:

"I am a native here, out of all residential location in this area, Bukit Cemara Tujuh is the high-end or luxurious residential location. Many houses are boarding houses and contracted, while the owners are out of town. The 
housing occupants are UMM students and immigrants who work in Malang. Anyway, the rich ones live here."

Taman Embong Anyar I and II, Sengkaling Pondok Indah, Taman Villa Sengkaling, Bumi Asri, and Landungsari Asri are middle-class residential complexes which covers an area of $80 \mathrm{~m}^{2}$ to $180 \mathrm{~m}^{2}$. The price in this residential area ranges from 350 Millions IDR to 600 Millions IDR. Graha Sengkaling, Djetis Regency, and Sengkaling Regency only consist of 30-50 houses. These residential locations are exclusive because they interface with the very firm kampong as native residential area and the residential locations are just 10 meters from the collector road of Dau District. Entrances to these residential locations are shown in the following figures.
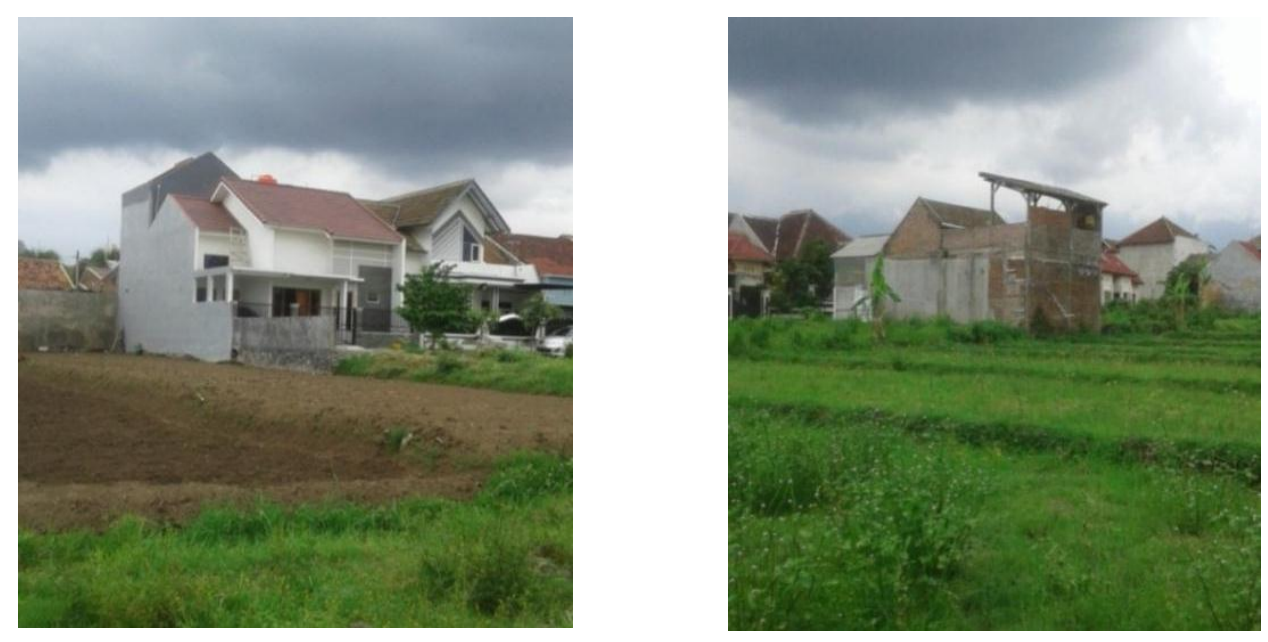

Figure 4. Paddy field undergoing conversion into residential land

Residential segregation in WSA is a phenomenon simultaneously occurring along with urban sprawl. Rubenstein (2008) asserts that residential segregation in suburb area happens by two means. The first is residential spread due to trading and manufacturing industry activities. The second is housings in WSA are built for people of a single social class. The residential segregation in WSA is shown to be the latter.

Residential segregation specifically indicates the land use polarization and social group distribution (K'Akumu et al, 2006; Surya, 2011). It's also as problem stating existence of discrimination and social ostracism, isolation of the vulnerability, and lack of a group (Musterd et al, 2005; Setioko, 2011). It means that unplanned residential growth in WSA of Malang leads to social segregation between migrants and natives.

Social segregation is shown from a low social interaction between migrants and natives. Migrants' form the social communities in their respective residential areas. Migrants do not spend much time outside their houses and outside residential neighbourhood. Even the migrants tend not to join social institutions and local wisdom prevailing in WSA. Mrs. W (56 years old) stated the following:

"Migrants do not want to mingle with us. If there is an event, such as 'tahlil' (religious gathering) and 'Agustusan' (Indonesian Independence Day), they do not join. If the migrants pass away, I won't express my sympathy. Why should I express my sympathy? They are only newcomers who are not natives here. Their houses are also not in the village, but in the residential areas." 
Jurnal Pendidikan Geografi:

Kajian, Teori, dan Praktik dalam Bidang Pendidikan dan Ilmu Geografi

Tahun 24, Nomor 1, Jan 2019, Hal 11-24

A migrant, Mr. A (47 years old) who has been living for 15 years in Bumi Asri Estate said:

"During my stay here, I have never participated in the village activities. If there is Agustusan, I take part in the celebration just in the housing area here. There is also a communal work in this area. There is a mosque here, so we do not need to go to the mosque in the village. We also often create our own activities, for example, the celebration of Independence Day, halal bihalal, and the birthday of the prophet",

Social segregation also shows that the social environment between the migrants and natives are not united. It creates social groups forcing people to adjust to the social environment. Each group follows the existing institutions in the social environment to sustain the community, the natural environment, and the development (Purba, 2005). However, residential segregation does not contribute crucial social problems as those occurring in developed countries. In most developed countries, residential segregation happens along with racial and ethnic segregations (Robinson, 2007).

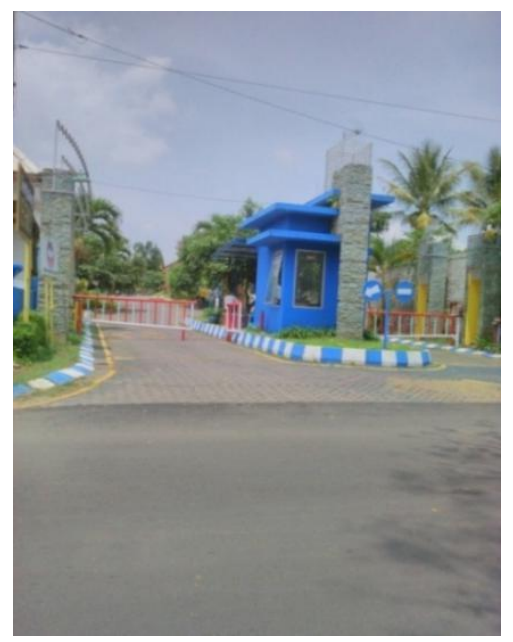

Figure 5. Entrance to the Sengkaling Regency Estate

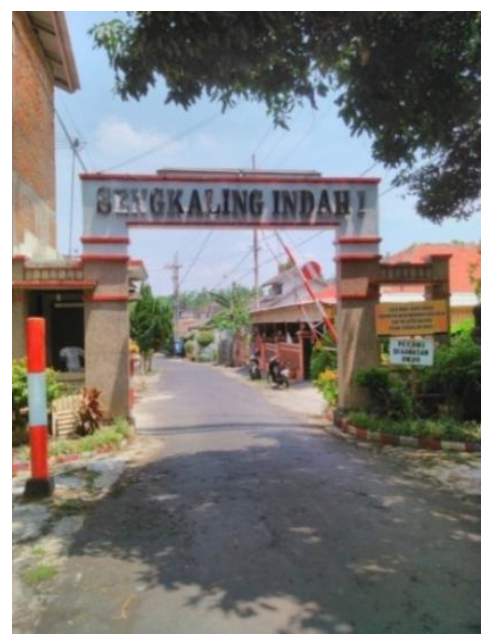

Figure 6. Entrance to Sengkaling Indah I estate 
Jurnal Pendidikan Geografi:

Kajian, Teori, dan Praktik dalam Bidang Pendidikan dan Ilmu Geografi

Tahun 24, Nomor 1, Jan 2019, Hal 11-24

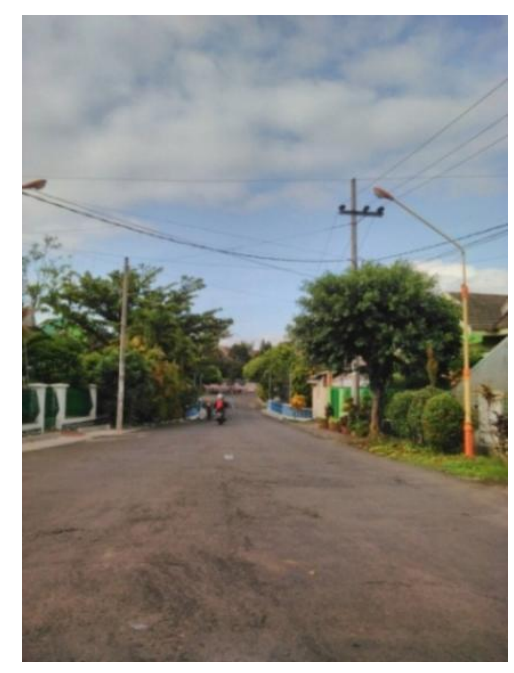

Figure 7. Villa Sengkaling Estate

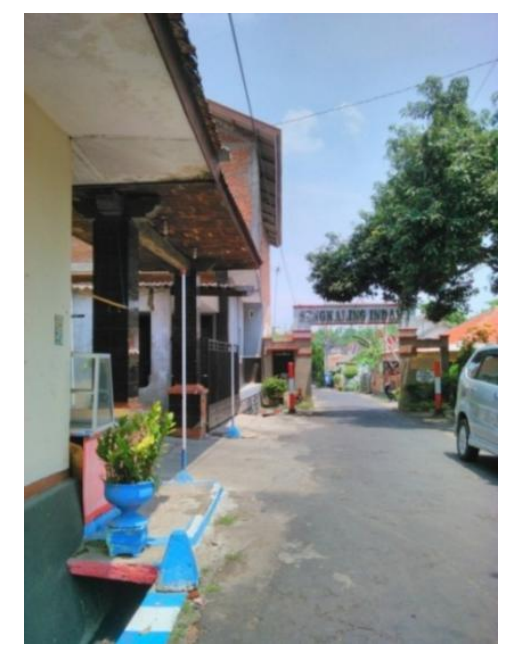

Figure 8. Residential Segregation

\section{CONCLUSION}

Urban sprawl process is caused by the centrifugal and centripetal forces. The centrifugal force is from the prime city of Malang due to the space limitation and the expensive price of land. Centripetal force comes from the suburb area namely the nature of locational and environmental rent. Both are the overlaps between economic and environment interests. Urban sprawl process also causes the spatial expression changed from rural into suburban areas. Spatial physical development only occurs in the primary arterial roads and areas with high accessibility to the primary arterial road. The spatial pattern formed is the ribbon development.

Urban sprawl process is started by the residential densification developed by private sectors as housing developers. This planned residential area is separated from the kampong. The result is that there is residential segregation which leads to the social segregation. Social interaction between migrants in the suburb area and the natives tends to be intertwined. Migrants and natives social environments are separated, and thus the social segregation is formed. 
Jurnal Pendidikan Geografi:

Kajian, Teori, dan Praktik dalam Bidang Pendidikan dan Ilmu Geografi

Tahun 24, Nomor 1, Jan 2019, Hal 11-24

\section{REFERENCES}

Ambarwati, L., Verhaeghe, R., Pel, A.J. \& van Arem, B. (2014). Controlling urban sprawl with integrated approach of space-transport development strategies. ProcediaSocial and Behavioral Sciences, 138, pp.679-694.

Blair, J.P. (1991). Urban and regional economics. Irwin. p394-449

Broitman, D. \& Koomen, E. (2015). Residential density change: Densification and urban expansion. Computers, environment and urban systems, 54, pp.32-46.

Brueckner, K.J \& Largey, G.A. (2008). Social interaction and urban sprawl. Journal of Urban Economics 64 (2008) 18-34

Colby, C.C. (2009). Centrifugal and centripetal forces in urban geography. Annals of the Association of Amerian Geographers. Volume XXIII March, 1933 No.1. Published Online 19 February 2009.

Daldjoeni, N. (2003). Geografi kota dan desa. Bandung: P.T Alumni Publisher.

Doling, J. and Ronald, R. eds. (2014). Housing East Asia: socioeconomic and demographic challenges. Springer.

Fatchan,A. (2013). Metode penelitian kualitatif: 10 langkah penelitian kualitatif pendekatan konstruksi dan fenomenologi. Malang: State University of Malang Publisher (UM Press)..

Fellmann, J.D., Getis, A. \& Getis, J. (2007). Human geography: Landscapes of human activities. New York: Mc Graw Hill.

Giyarsih, R.S. (2011). Gejala urban sprawl sebagai pemicu proses densifikasi permukiman di daerah pinggiran kota (urban fringe area) kasus pinggiran kota Yogyakarta. Area and City Planning Journal 12.1 (2011):39-45.

Glaeser, E.L \& Kahn, M.E. (2003). Sprawl and urban growth. NBER Working Paper Series No 9733. National Bureau of Economic Research. 1050 Massachusetts Avenue. Cambridge.

Kinanti, A.S. \& Handayani, W. (2013). Perkembangan wilayah peri urban: Kajian pada perspekstif demografi dan kondisi sosial ekonomi masyarakat (studi kasus: Kecamatan Depok, Kabupaten Sleman). Teknik PWK (Perencanaan Wilayah Kota), 2(3), pp.727-737

K'Akumu, O.A. \& Olima, W.H. (2007). The dynamics and implications of residential segregation in Nairobi. Habitat International, 31(1), pp.87-99.

Knox, P.L., Marston, S.A. \& Imort, M. (2016). Human geography: Places and regions in global context. Pearson.

Liu, Y., Dijst, M., \& Geertman, S. (2015). Residential segregation and well-being inequality over time: A study on the local and migrant elderly people in Shanghai. Cities, 49, pp.1-13.

Mohammadi, J., Zarabi, A., \& Mobaraki, O. (2012). Urban sprawl pattern and effective factors on them: The case of Urmia City, Iran. Journal of Urban \& Regional Analysis, 4(1).

Mubarak, FA. (2004). Urban growth boundary policy and residential suburbanization: Riyadh, Saudi Arabia. Habitat International 28 (2004) 567-591.

Musterd,S \& Ostendorf, W. (2005). Urban Segregation and the Welfare State: Inequality and exclusion in Western Cities. New York: Routledge 270 Madison Ave.

Nechyba, T.J. \& Walsh, R.P. (2004). Urban sprawl. Journal of economic perspectives, 18(4), pp.177-200.

Nurmandi, A. (2014). Manajemen perkotaan: Teori organisasi, perencanaan, perumahan, pelayanan dan transportasi mewujudkan kota cerdas. Yogyakarta: Jusuf Kalla School of Goverment Universitas Muhammadiyah Yogyakarta (JKSG UMY). 
Jurnal Pendidikan Geografi:

Kajian, Teori, dan Praktik dalam Bidang Pendidikan dan Ilmu Geografi

Tahun 24, Nomor 1, Jan 2019, Hal 11-24

Overman, H. (2006). In brief urban sprawl. Centre Piece Summer 2006. Economic Geography at LSE and An Associate in CEP's Globalisation Programme.

Purba, J. (2005). Pengelolaan lingkungan sosial. Jakarta: Yayasan Obor Indonesia.

Robinson, D. (2007). Living parallel lives? Housing, residential segregation and community cohesion in England. Neighbourhood Renewal \& Housing Markets: Community Engagement in the US \& UK, pp.163-185.

Rubenstein, J.M. \& Bacon, R.S. (2008). The cultural landscape: An introduction to human geography. Upper Saddle River, New Jersey: Prentice Hall.

Santoso, E.B. (2009). Menuju penataan ruang perkotaan yang berkelanjutan, berdaya saing, dan berotonomi. Proceeding of National Seminar of Area and City Planning ITS, Surabaya,29 October 2009

Sastrawati, I \& Santoso, L. (2011). Perubahan guna lahan di suburban selatan kota Makasar. Group of Architecture Engineering. Volume 5 December 2011

Maru, R., Ikhsan, M. \& Laka, B.M. (2016). Perubahan penggunaan lahan Kota Makassar tahun 1990-2010. Sainsmat, 4(2).

Serlin, M.A., \& Umilia, E. (2013). Faktor-faktor yang memengaruhi masyarakat dalam memilih lokasi hunian peri urban Surabaya di Sidoarjo. Engineering Journal Vol. 2 No. 2

Soetomo, S. (2002). Strategi desain ruang sub-urban dalam menopang pembangunan yang berkelanjutan. pidato pengukuhan untuk jabatan guru besar pada Fakultas Teknik Universitas Diponegoro, Semarang. Retrieved from

http://eprints.undip.ac.id/290/1/Sugiono_Soetomo.pdf

Setioko, B. (2013). Konsep kearifan lokal pada pertumbuhan kawasan pinggiran kota. MODUL, 13(2).

Suman, A. (2012). Desain penelitian: Pendekatan kualitatif. Malang: Insan Muamalah Publisher (Anggota of IKAPI).

Surya, B. (2011). Perubahan fisik spasial kawasan pinggiran memarginalkan komunitas lokal (Kasus Kota Baru Metro Tanjung Bunga, Makassar). Tataloka, 13(4), pp.212223

Vaz, E. \& Nijkamp, P. (2015). Gravitational forces in the spatial impacts of urban sprawl: An investigation of the region of Veneto, Italy. Habitat International, 45, pp.99105.

Wagistina, S., Suman, A., Antariksa, A. \& Yanuwiadi, B. (2017). Urban sprawl, suburbanization, and informal sector in Western Suburb Area-Malang City-East Java. WACANA, Jurnal Sosial dan Humaniora, 20(2).

Yunus, H.S. (2012). Struktur tata ruang kota. Yogyakarta: Pustaka Pelajar.

Yunus, H.S. (2010). Dinamika wilayah peri-urban: Determinan masa depan kota. Yogyakarta: Pustaka Pelajar. 